\title{
$\sqrt{7}$ 根尖部病変に近接していた静止性骨空洞の 1 例
}

\author{
秋葉正一・青木秀史・尾嶋徹
}

\section{A case of static bone defect: Bone defect situated below the radicular cystic lesion of 2 nd molar}

\author{
Masakazu Aкıвa • Hidefumi Aoki • Toru OJima
}

Key words: static bone defect (静止性骨空洞), salivary gland (唾淮腺), sialography (哽液腺 造影)

\section{緒}

\section{言}

一般に静止性骨空洞は，下買管の下方で下䫇角から第 3 大曰歯の間に, 直径約 $1 \sim 3 \mathrm{~cm}$ の円形ないし類円形 の, 周囲との境界が比較的明瞭な孤立性の堡胞様骨欠損 像として認められている。著者らは， $7 \overline{78}$ の根尖部に境 界不明瞭なX線半透過像を有する患者に遭遇し，精査の 結果, 異所性の買下腺に起因する静止性骨空洞之䛦断乙 た 1 症例を経験したので，その概要を報告する.
症
例

患 者: 27歳 男性.

初診: 平成 2 年 6 月国。

主 訴: $\overline{8}$ 周囲の齿肉の痛み,

既往歴・家族歴：特記すべき事項なし。

現病歴：約 1 年前から $\sqrt{8}$ 周团の崡肉に疼痛が生し， 腫脹をくり返した。

全身所見：体格，栄盖状態に異常所見はなかった。

現 症：口腔外化異常所見は認められず，口腔内所見 では $\sqrt{8}$ が半埋伏状態であり, 7 にはインレーが装着さ れているか゚舌側根尖相当部粘膜に瘻孔が認められた。

$\mathbf{X}$ 線所見： 17 根尖部は荬慒白線の消失之，根尖を含 む円形のX線半透過像が， 18 の根尖部直下には境界不 明膫な類円形のX線半透過像が認められ，雨者の間には 骨様不透過像があり，また，それらの中に下頻管が重複 して䜑められた（写真1）。

これらの所見より， 77 根尖部のX線半透過像は $\sqrt{7} か ゙$ 原因の慢性炎症によるもの之診断した。 しかし $\sqrt{8}$ 根尖 部直下のX線半透過像については， $\mid \overline{8}$ が生活荘考克 られること，歯根周囲の白線が明瞭であること，また，

総合病院国保旭中央病院料科口腔外科

（主任：秋集正一部長）

Department of Dentistry and Oral Surgery, Asahi

General Hospital (Chief: Masakazu Akiba)

受付日: 平成 3 年 3 月 18 日

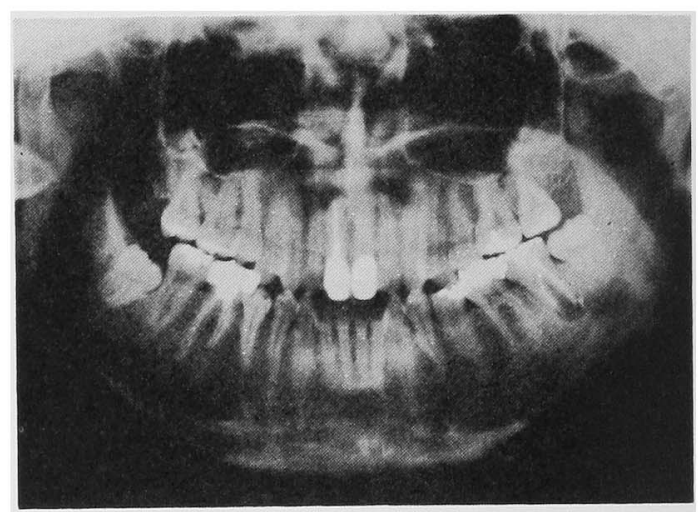

写真 1 初喰時バラマX線所見

わずかではあるが，根尖と離れていることなどから非菌 原珄と考党られた。

精查のために追加したX線 CT 像（写真 2）では，矢 印のごとく，下䫇骨骨体に涩められる類円形透過像の一 部に舌側皮質骨の欠損像を認め，骨欠損部内之口腔軟組 織とのX線 CT 像の密度は同程度であった。パノラマX 線写真扣よびX線 CT 写真の所見より，口腔軟組織（特 に枵下腺）との関連を㬵い，顎下腺造影検查（写真了） を行った．造影所見では頇下腺管は途中で 2 分してお り，1つは下方へ，他は店下の骨欠損腔内へ入って いた。

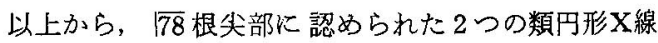
不透過像は，可に起因する根尖性雪周炎およびそれに隣 接する静止性骨空洞と臨床診断した.

\section{処 置}

$\sqrt{7}$ に対しては抜齿と根尖部の提爬を，18 に対しては 歯肉弁切除を施行し，静止性骨空洞に対しては特に処置 を行わず経過観祭とした。 な执， 7 の根头病巣と静止 性骨空洞とは硬い硬組織で境されており，交通は認めら れなかった。 

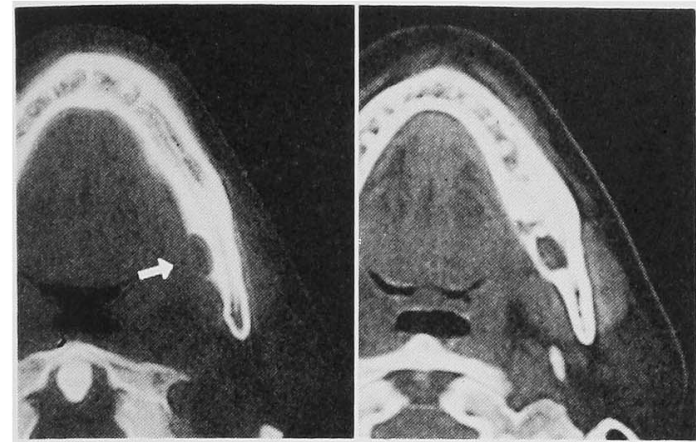

写真 $2 \mathrm{X}$ 線 CT 所見（矢印は舌側皮質骨の欠損像）

考

察

静止性骨空洞の発見年龄は，われわれが渉猟し得た限

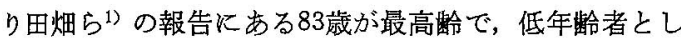
ては Hansson 2)が初診時下靧に巽常を認めなかった11藏 の男子について，矯正治療開始後のX線検查（初診より 18か月）にて本症の存在を発見したと報告して扣りこ の報告例が最年少と思われた。 また，本症発見の平均年 龄については Stafne ${ }^{33}$ は53.4歳，古跡ら ${ }^{4)}$ は47.4歳と述 ベて拈り，男女比について Stafne ${ }^{32}$ は28対 6 ，古跡ら は 52 対10 と報告しているが，両報告とる約 5 対 1 の割合 で男性に多く，人種差は認められなかった，本症例は27 歳の男性であり，低年㱓者の範疇に入るものと考光られ た.

高谷ら ${ }^{5)}$ は1942 1983年をでの報告例について文献検 索行い，230例中206例 (89.6\%) が下龥角付近に存在 していたと述べているが，その内容については，外科的 検索を受けた58例に打いて，39例（67.3\%）が唾液腺組 織であったと報告している。

成因については現在まで確定されておらず，そのため 㭔称もさまざまである。しかし，内容物の大部分が正 常唾夜腺組織であることや好発部位などから，近年にお いては周用組織の圧迫によって生でた後天的な骨欠損で あるといら考方方が支持され，Bone defect の名称が適 当之考学られている6,7).

崄断括いても同様の理由から, 通常のX線㭘查の他 に，䪽下腺造影撮影8)を施行することが必要とされてい るが，X線 CT 撮影や買下腺造影 $\mathrm{X}$ 線 $\mathrm{CT}$ 撮影も有効と 考完られる。

一般に本病態は著明な骨硬化像を示す病変辺縁と下罰 骨皮質骨が連続している特徵のある所見》が得られると いらが，本症例では，この所見は認められなかったこ 之, 下瀕管との重複像が認められたこと，さらに半透過 像の上縁が $\mid \overline{8}$ の根尖付近にまで波及していたことなど，

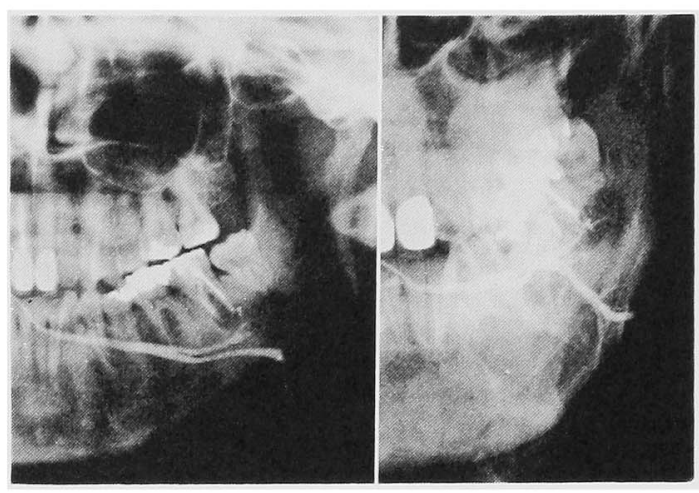

写真 3 顎下腺造影所見

典型的な静止性骨空洞とはそのX線写真像を異にしてお り, 当初 $\mid 7$ の根尖部病変の拡大とも考支たが，X線 CT 撮影・晴液腺造影撮影により鑑別し得たので，これらの 撮影法併用の有用性を再確認したものである。

$$
\text { 結 語 }
$$

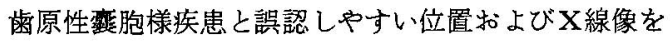
示した静止性骨空洞の 1 例を経験したので報告した。

\section{引用 文 献}

1) 田畑 修，黒木敬士，他：䪽下腺造影により確 認された “Static Bone Defect”の 1 例. 迷放 22: 348-349 1983.

2) Hansson, L.-G.: Development of a lingual mandibular bone cavity in an 11-ycar-old boy. Oral Surg 49: 376-378 1980.

3) Stafne, E.C.: Bone cavities situated near the angle of the mandible. J Am Dent Assoc 29: 1969-1972 1942.

4））古跡孝和，川崎靖典，他：静止性骨空洞のX 線診断的検討 (62症例) (抄). 海放 28: 353 1988.

5）高谷康男，西嶋克巳，他：Idiopathic Bone Cavityの 2 症例扰よびその文献的考察。口科誌 34: 225-232 1985.

6) Karmiol, M. and Walsh, R.F.: Incidence of static bone defect of the mandible. Oral Surg 26: 225-228 1968.

7) 江原昌弘, 内海潔, 他：いわゆる Developmental Bone Defect 24 症例のエックス線写真 的検索. 潾放 17: 44-51 1977 .

8）佐藤則，埜口五十雄，他：顎下腺造影により 診断した静止性骨空洞の 1 例。 日口外誌 34 : 1437-1443 1988. 